\title{
PENGARUH PENGAWASAN KEUANGAN PADA DAERAH-DAERAH DI INDONESIA TERHADAP TINGKAT KORUPSI DI INDONESIA
}

\author{
Ida Ayu Putri Anjani, Ketut Suriani, Santi Widyasih, Kadek Mahayoni, Gede \\ Budi Utama, I Gede Agus Yudi Darma Putra \\ Jurusan Akuntansi, Universitas Pendidikan Ganesha, Singaraja, Bali, Indonesia
}

\begin{abstract}
Abstrak
Penelitian ini bertujuan untuk menginvestigasi pengaruh opini audit terhadap tingkat korupsi di Indonesia dan pengaruh temuan audit terhadap tingkat korupsi di Indonesia. Penelitian ini termasuk tipe penelitin kepustakaan dengan menggunakan sumber data berupa hasil-hasil penelitian terdahulu yang relevan. Hasil peneltian menunjukkan bahwa semakin baik opini audit yang diperoleh menunjukkan semakin rendah potensi korupsi di lingkungan pemerintah daerah sehingga opini audit dihipotesiskan berpengaruh negatif terhadap persepsi korupsi. Selain itu, semakin baik opini audit yang diperoleh menunjukkan semakin rendah potensi korupsi di lingkungan pemerintah daerah sehingga opini audit dihipotesiskan berpengaruh negatif terhadap persepsi korupsi.
\end{abstract}

Kata kunci: opini audit; temuan audit; tingkat korupsi

\begin{abstract}
This study aims to investigate the effect of audit opinion on the level of corruption in Indonesia and the effect of audit findings on the level of corruption in Indonesia. This research belongs to the type of literature research using data sources in the form of relevant previous research results. The results of the study indicate that the better the audit opinion obtained shows the lower the potential for corruption in the local government environment so that the audit opinion is hypothesized to have a negative effect on the perception of corruption. In addition, the better the audit opinion obtained shows the lower the potential for corruption in the local government environment so that the audit opinion is hypothesized to have a negative effect on the perception of corruption.
\end{abstract}

Keywords: audit opinion; audit findings; level of corruption

\section{Pendahuluan}

Pengawasan adalah proses pengamatan daripada pelaksanaan seluruh kegiatan organisasi untuk menjamin agar supaya semua pekerjaan yang sedang dilakukan berjalan sesuai dengan rencana yang telah ditentukan sebelumnya (Siagian, 1990:107). Dengan adanya pengawasan tentunya diharapkan kinerja dari organisasi pemerintah menjadi semakin lebih baik dan berjalan sesuai dengan tujuan sebenarnya. Di dalam proses pengawasan tentunya terdapat temuan-temuan audit beserta bukti-bukti audit yang dapat menghasilkan opini audit yang merupakan hasil dari pengawasan yang dilakukan oleh BPK. Opini audit merupakan faktor penting yang menjadi tolak ukur dari efektivitas pengawasan dan penilaian kinerja pengelolaan keuangan pemerintah daerah (Giroux, 1989; Virgasari, 2009). Pemberian opini audit BPK digunakan oleh Kementerian Keuangan sebagai salah satu indikator pemberian reward dan punishment. Pemerintah daerah akan memperoleh intensif tambahan jika memenuhi tiga jenis kriteria dalam sistem pemberian reward tersebut, yang salah satunya adalah memproleh opini WPT (Kurnia, 2013). Contoh lainnya adalah di Kementerian Perindustrian yang menjadi salah satu kementerian yang masuk dalam daftar untuk mendapatkan renumerasi karena memperoleh opini WPT selama lima kali (www.ksap.org). Secara keseluruhan proses audit di sektor public dapat meningkatkan transparansi dan akuntanbilitas (Dwiputrianti, 2008) serta membantu mencegah adanya tindakan korupsi (Dye dan Straphenhurst 1998, Khan 2006). Meskipun Khan (2006) menekankan bahwa auditor hanya berperan dalam membantu menunjukkan wilayah dimana kemungkinan tindakan korupsi dapat terjadi. Lebih jauh lagi, pemeriksaan dalam institusi pemerintahan juga berkontribusi untuk memastikan kepatuhan terhadap hukum dan 
peraturan (Raman dan Wilson, Nosworthy 1999, Dwiputriani 2008). Pengawasan keuangan secara signifikan mempengaruhi tingkat korupsi di Indonesia terutama pada pengawasan terhadap pengelolaan keuangan Negara karena berbicara masalah keuangan tentunya rentan dengan manipulasi laporan keuangan dan kurangnya transparansi dari hasil audit yang dilakukan atas pengawasan keuangan tersebut. Tugas utama Badan Pengawas Keuangan Negara (BPK) adalah memeriksa pengelolaan dan tanggung jawab keuangan Negara serta menyerahkan semua hasil pemeriksaan tersebut kepada lembaga perwakilan untuk mendorong transparansi dan akuntabilitas penyelenggaraan keuangan negara sebagai hal utama dalam demokrasi ekonomi dan politik yang sesungguhnya. Fenomena korupsi yang banyak terjadi di Indonesia pada era reformasi, hal ini menyebabkan semakin kecilnya kepercayaan masyarakat terhadap kinerja pemerintah. Dewasa ini sering kali terjadi kasuskasus korupsi yang berkaitan dengan kurangnya pengawasan dan transparasi dari hasil audit yang dilakukan oleh BPK serta temuan-temuan dan bukti-bukti audit yang kurang akurat sehingga opini audit tersebut diragukan kebenarannya. Berdasarkan latar belakang tersebut, maka rumusan masalah yang akan kami bahas pada penelitian ini adalah pengaruh opini audit terhadap tingkat korupsi di Indonesia, pengaruh temuan audit terhadap tingkat korupsi di Indonesia.

Berdasarkan latar belakang, rumusan masalah yang didapat adalah bagaimana pengaruh opini audit terhadap tingkat korupsi di Indonesia dan bagaimana pengaruh temuan audit terhadap tingkat korupsi di Indonesia.

\section{Pembahasan}

\subsection{Pengaruh Opini Audit Terhadap Tingkat Korupsi Di Indonesia}

Opini audit menurut kamus standar akuntansi (Ardiy, 2007) adalah laporan yang diberikan seorang akuntan public terdaftar sebagai hasil penilaiannya atas kewajaran laporan keuangan yang disajikan perusahaan. Sedangkan menurut kamus istilah akuntansi (Tobing, 2004) Opini audit merupakan suatu laporan yang diberikan oleh auditor terdaftar yang menyatakan bahwa pemeriksaan telah dilakukan sesuai dengan norma atau aturan pemeriksaan akuntan disertai dengan pendapatan mengenai kewajaran laporan keuangan yang diperiksa. Opini audit diberikan oleh auditor melalui beberapa tahap audit sehingga auditor dapat memberikan kesimpulan atas opini yang harus diberikan atas laporan keuangan yang diauditnya.

Jenis-jenis Opini Audit

Menurut standar professional akuntan (PSA 29), opini audit terdiri dari 5 jenis yaitu:

a. Opini wajar tanpa pengecualian (Unqualified opinion)

Adalah pendapat yang diberikan ketika audit telah dilaksanakan sesuai dengan Standar Auditing (SPAP), auditor tidak menemukan kesalah material secara keseluruhan laporan keuangan atau tidak terdapat penyimpangan dari prinsip akuntansi yang berlaku (SAK). Bentuk laporan ini digunakan apabila terdapat keadaan berikut:

1. Bukti audit yang dibutuhkan telah terkumpul secara mencukupi dan auditor telah menjalankan tugasnya sedemikian rupa, sehingga ia dapat memastikan kerja lapangan telah ditaati.

2. Ketiga standar umum telah diikuti sepenuhnya dalam perikatan kerja.

3. Laporan keuangan yang diaudit disajikan sesuai dengan prinsip akuntansi yang lazim yang berlaku di Indonesia yang ditetapkan pula secara konsisten pada laporanlaporan sebelumnya.

4. Tidak terdapat ketidakpastian yang cukup berarti (no material uncertainties) mengenai perkembangan di masa mendatang yang tidak dapat diperkirakan sebelumnya atau dipecahkan secara memuaskan.

b. Opini Wajar Tanpa Pengecualian dengan Paragraf Penjelasan (Modified Unqualified Opinion)

Adalah pendapatan yang diberikan ketika suatu keadaan tertentu yang tidak berpengaruh langsung terhadap pendapat wajar. Keadaan tertentu dapat terjadi apabila:

1. Pendapat auditor sebagian didasarkan atas pendapatn independen lain. 
2. Karena belum adanya aturan yang jelas maka laporan keuangan dibuat menyimpang dari SAK.

3. Laporan dipengaruhi oleh ketidak pastian peristiwa masa yang akan dating hasilnya belum dapat diperkirakan pada tanggal laporan audit.

4. Terdapat keraguan yang besar terhadap kemampuan suatu usaha dalam mempertahkan kelangsungan hidupnya.

5. Diantara dua periode akuntansi terdapat perubahan yang material dalam penerapan prinsip akuntansi.

6. Data keuangan tertentu ng diharuskan ada oleh BAPEPAM namun tidak disajikan.

c. Opini Wajar Dengan Pengecualian (Qualified Opinion)

Adalah pendapat yang diberikan ketika laporan keuangan dikatakan wajar dalam hal yang material, tetapi terdapat suatu penyimpangan/ kurang lengkap pada pos tertentu, sehinga harus dikecualikan. Dari pengecualian tersebut yang dapat mungkin terjadi, apabila:

1. Bukti kurang cukup

2. Adanya pembatasan ruang lingkup

3. Terdapat penyimpangan dalam penerapan prinsip akuntansi yang berlaku umum (SAK)

d. Opini tidak wajar (Adverse Opinion)

Adanya pendapatan yang diberikan ketika laporan secara keseluruhan ini dapat terjadi apabila auditor harus memberi tambahan paragraph untuk menjelaskan ketidakwajaran atas laporan keuangan, disertai dengan dampak dari akibat ketidakwajaran tersebut, pada laporan auditnya.

e. Opini Tidak Memberikan Pendapat (Disclaimer of opinion)

Adalah pendapat yang diberikan ketika ruang lingkup pemeriksaan yang dibatasi, sehingga auditor tidak melaksanakan pemeriksaan sesuai dengan standar auditing yang ditetapkan IAI.

Tahap-tahap Opini Audit

Sebelum auditor memberikan pendapat (opininya), seseorang auditor harus melaksanakan tahap-tahap audit. Adapun tahap-tahapnya menurut Arens etal (2008:132) yaitu sebagai berikut:

1. Perencanaan dan pencanangan pendekatan audit.

2. Pengujian pengendalian dan transaksi.

3. Pelaksanaan prosedur analitis dan pengujian terinci atas saldo.

4. Penyelesaian dan penerbitan laporan audit.

Opini audit merupakan pernyataan auditor atas kewajaran informasi keuangan yang disajikan dalam laporan keuangan, sehingga opini audit dapat digunakan oleh pengguna laporan keuanagn dan memberikan keyakinan bahwa informasi audit pada laporan keuangan organisasi lain adalah bahwa opini audit juga menggambarkan kepatuhan atas peraturan perundang-undangan serta efektivitas sistem pengendalian intern. Zawitri (2009) mengutip dari pernyataan Gubernur Lenhanas bahwa opini audit menggambarka penerapan 'prinsip-prinsi tata kelola pemerintah terutama prinsip akuntabilitas dan transparansi sehingga dapat mempengaruhi kepercayaan masyarakat terhadap penyelenggaran pemerintahan. Opini audit merupakan hasil dari proses audit dan salah faktor yang dapat menggambarkan kualitas audit (Wibowo dan Rossieta, 2009). Hal serupa juga dinyatakan dalam Setyowati (2013) yang berpendapat bahwa kualitas pengelolaan keuangan pemerintah daerah dapat diketahui dari opini audit, sehingga opini audit pemerintah daerah digunakan sebagai pertimbangan oleh pemerintah pusat dalam menilai kinerja pemerintah daerah. Hubungan antara opini audit dan kinera pemerintah daerah telah dibuktikan secara empiris oleh Virgasari (2009) dimana opini audit memiliki pengaruh positif yang signifikan terhadap kinerja pemerintah daerah. Hal ini membuktikan bahwa semakin baik opini audit yang diperoleh pemerintah daerah menunjukkan penilaian kinerja pemerintah daerah yang baik. Kinerjja pemerintah daerah yang dinilai baik dapat menunjukkan rendahnya potensi penyimpangan di lingkungan pemeritah di daerah tersebut. Semakin baik opini audit yang 
diperoleh menunjukkan semakin rendah potensi korupsi di lingkungan pemerintah daerah sehingga opini audit dihipotesiskan berpengaruh negatif terhadap persepsi korupsi.

Berdasarkan survey yang dilakukan ACFE lemahnya pengendalian interen menjadi penyebab utama terjadinya kecurangan. Hasil yang juga ditemukan dari hasil survey KPMG yang dikutip dalam Huefner (2011) yang membuktikan bahwa penyebab yang paling signifikan atas kecurangan yang terjadi dipemerintahan adalah lemahnya pengendalian intern. Dengan adanya sistem pengendalian intern yang baik, organisasi dapat meminimalisasi kecurangan dan meningkatkan peluang untuk mendeteksi kesalahan dalam akuntansi, yang dilakukan baik dengan sengaja maupun tidak (DeFond dan Jiambalvo, 1991). Huefner (2011) menyatakan bahwa cara yang utama untuk mencegah terjadinya kecurangan yaitu dengan adanya sistem pengendalian intern yang kuat. Petrovits et al. (2009) meneliti organisasi non profut yang menggunakan dana yang berasal dari donor publik dimana hasil penelitiannya membuktikan bahwa penonor bereaksi atas informasi mengenai pengendalian intern baik langsung maupun tidak langsung. Hal ini memberikan kesimpulan bahwa sistem pengendalian intern merupaka aspek yang amat penting dalam pengelolaan organisasi termasuk organisasi pemerintah. Huefner (2011) juga melakukan penelitian mengenai kasus kelemahan pengendalian intern di pemerintah daerah yang diperoleh dari rincian laporan audit. Berdasarkan penelitian yang dilakukan Huefner (2011), temuan audit atas sistem pengendalian intern dapat digunakan untuk mendeteksi adanya potensi kecurangan dilingkungan pemerintah daerah.

Menurut Olken, 2007 tidak banyak studi yang membahas keterkaitan antara audit pemerintah dengan korupsi. Penelitian tentang bagaimana untuk mengurangi korupsi jarang memberi perhatian khusus terhadap peran audit, opini audit, dan kinerja pemerintah. Hanya beberapa studi yang menyentuh pada hubungan audit pemerintah dan korupsi. Namun, tidak satupun dari studi tersebut menjawab pertanyaan tentang bagaimana audit pemerintah dapat membantu untuk memberantas korupsi (Liu dan Lin, 2012).

Secara keseluruhan proses audit disektor public dapat meningkatkan transparansi dan akuntabilitas (Dwiputrianti, 2008) serta membantu mencegah adanya tindakan korupsi (Khan, 2006). Meskipun Khan, 2006 menekankan bahwa auditor hanya berperan dalam membenatu menunjukan wilayah dimana kemungkinan tindakan korupsi dapat terjadi. Lebih jauh lagi, pemeriksaan dalam institusi pemerintahan juga berkontribusi untuk memastikan kepatuhan terhadap hokum dan peraturan (Dwiputrianti, 2008).

Beberapa penelitian lainnya terkait korupsi menunjukan bahwa terdapat kaitan antara opini yang diberikan BPK RI dengan korupsi, yaitu opini yang baik mengindikasikan bebas dari korupsi ( Rini dan Sarah, 2014). Penelitian Rini dan Sarah, 2014 mendukung penelitian Khair, 2015 yang mengungkapkan bahwa opini audit dan sistem pengendalian internal berpengaruh signifikan terhadap kerugian Negara yang mengindikasikan adanya penyimpangan. Hali penelitian Masyitoh dkk, 2015 membuktikan bahwa opini audit, temuan audit atas ketidakpatuhan terhadap peraturan perundang-undangan serta tindak lanjut audit berpengaruh terhadap persepsi korupsi. Selanjutnya Liu dan Lin, 2012 juga mengungkapkan melalui penelitian yang mereka lakukan, bahwa jumlah ketidakberesan dalam pendapatan dan belanja pemrintah yang dideteksi oleh institusi audit local akan berkaitan secara signifikan dengan tingkat korupsi.

Hasil berbeda diungkapkan oleh Heringingsih dan Marita, 2013 dalam penelitiannya yang menyatakan bahwa opini audit tidak berpengaruh terhadap tingkat korupsi. Menurut Effendy, 2013 opini atau hasil audit Badan Pemeriksa Keuangan (BPK) tidak dapat dipastikan bahwa dapat menjamin baik dan buruknya pengeolaan keuangan.

\subsection{Pengaruh Temuan Audit Terhadap Tingkat Korupsi Di Indonesia}

\section{Definisi Temuan Audit}

Temuan audit adalah himpunan data dan informasi yang dikumpulkan, diolah dan diuji selama melaksanakan tugas audit atas kegiatan instansi tertentu yang disajikan secara analitis menurut unsure-unsurnya yang dianggap bermanfaat bagi pihak-pihak yang berkepentingan. Temuan audit merupakan hasil pemeriksaan BPK yang menunjukkkan 
temuan audit baik temuan atas pengendalian internal maupun temuan atas ketidakpatuhan atas peraturan dan perundang-undangan.

Sifat Temuan Audit

1. Temuan audit dapat memiliki berbagai bentuk \& ukuran.

2. Temuan audit sering disebut kekurangan (deficiencies)

3. Istilah "temuan "cenderung terlalu negatif, sedang "kondisi" relatif lebih tepat dan tidak menimbulkan sikap defensive bagi auditee.

4. Temuan audit menjelaskan bahwa sesuatu yang baik saat sekarang (current) atau masa lalu (histories) serta yang mungkin terjadi dimasa yang akan dating (future) terdapat masalah.

Standar 2310 SPPIA :

1. Auditor internal harus mengidentifikasi informasi yang cukup (sufficient), relevan (relevance), andal (reliable) dan berguna (usefulness) untuk mencapai tujuan penugasan.

2. Practice advisory 2410-1 dari Standar :" criteria komunikasi". Observasi dan rekomendasi harus didasarkan pada atribut : criteria, kondisi, penyebab \& dampak.
a. Criteria (criteria) : standar, ukuran atau ekspetasi yang dipakai untuk evaluasi/verifikasi (apa yang harus ada/harapan).
b. Kondisi (condition) : bukti factual yang ditemukan saat pengujian (apa yang ada/kenyataan).
c. Penyebab (causes) : alasan perbedaan antara harapan dengan kondisi actual (mengapa ada perbedaan).
d. Dampak (effect) : resiko/eksposur yang dihadapi organidasi karena kondisi tidak sama dengan criteria (akibat perbedaan)

3. Pracrice advisory 2420-1 dari standar :" kualitas criteria komunikasi" a.1 : obyektif,jelas,ringkas,konstruktif \& tepat waktu.

4. Saran-saran untuk perbaikan (suggestion for improvement).
a. Temuan audit membutuhkan tindakan perbaikan.
b. Manajer operasi memiliki hak untuk mengimplementasikan saran tersebut atau tidak.

5. Temuan audit yang dapat dilaporkan.

a. Tidak setiap kelemahan dapat dilaporkan

b. Temuan audit yang dapat dilaporkan, harus memiliki kreteria : cukup signifikan, didasarkan fakta, obyektif, relevan dan cukuo meyakinkan.

Unsur-unsur temuan audit

Unsur-unsur temuan audit meliputi:

1. Kondisi

Merupakan keadaan atau kejadian sebernya ditemuan audit selama proses audit dilaksanakan dan diselesaikan

2. Kriteria

Dua elemen penting dalam konsep criteria (criteria) yaitu tujuan dan sasaran, bias mencakup standar operasional yang di audit dan kualitas pencapaian

3. Akibat

Resiko atau eksposur yang dihadapi organisasi karena kondisi tidak sama dengan criteria (akibat perbedaan)

4. Sebab

Merupakan alas an perbedaan harapan dengan kondisi actual (mengapa ada perbedaan)

5. Kesimpulan

Harus ditunjang oleh fakta-fakta. Kesimpulan dapat dan seharusnya menyajikan tindakan potensial.

6. Rekomendasi

Mengambarkan tindakan yang mungkin dipertimbangkan manajemen untuk memperbaiki kondisi-kondisi yang salah dan untuk memperkuat kelemahan dalam sistem control. 
Penelitian terhadap temuan audit yang dilakukan oleh Mustikarini (2012) menemukan bahwa ukuran pemda, tingkat kekayaan, ketergantungan pemerintah pusat berpengaruh positif sedangkan belanja daerah dan temuan audit berpengaruh negative terhadap kinerja pemda. Pengendalian intern dan ketidakpatuhan terhadap perundang-undangan sering di identikkan dengan pengendalian akuntansi dan keuangan karena frekuensi pelanggaran dan besarnya kerugian yang ditimbulkan lebih signifikan terjadi pada bidang ini.

Zaelani (2010) juga melakukan penelitian terhadap temuan audit atas system pengendalian intern pemerintah tahun 2008. Hasil penelitian tersebut mengatakan bahwa banyak terdapat kelemahan yang ditemukan di setiap pemerintah daerah. Umumnya, kelemahan pada system pengendalian intern dan ketidakpatuhan terhadap perundangundangan di lembaga pemerintahan dimanfaatkan oleh pihak-pihak yang tidak bertanggung jawab untuk mengambil keuntungan dan kecurangan yang biasa dilakukan di mulai dari tahap penyusunan angggaran sampai kecurangan dalam pengadaan barang. Menurut Wilopo (2006) dalam Zaelani (2010) pada umumnya kecurangan akuntansi berkaitan dengan korupsi. Dalam korupsi, tindakan yang lazim dilakukan diantaranya adalah memanipulasi pencatatan, penghilangan dokumen, dan mark up yang merugikan keuangan Negara atau perekonomian Negara. Pengendalian intern dan kepatuhan terhadap perundang-undangan tidak sebatas pada pengendalian akuntansi dan keuangan saja tetapi meliputi keseluruhan organisasi.

Berdasarkan UU No.15/2004 hasil pemeriksaan BPK selain dari opini audit juga dapat berupa temuan audit. Hasil pemeriksaan BPK atas temuan audit dibagi menjadi dua yaitu temuan audit atas system pengendalian intern dan temuan audit atas ketidakpatuhan terhadap perundang-undangan. Huefner, 2011 melalui penelitiannya menyatakan bahwa cara yang utama untuk mencegah terjadinya kecurangan yaitu dengan adanya system pengendalian internal yang kuat. Sehingga semakin banyak temuan kelemahan pengendalian internal akan meningkatkan kemungkinan terjadinya korupsi.

Ferraz dan Finan, 2011 menyatakan peraturan dalam pemerintahan dapat meningkatkan akuntabilitas yang memainkan peran penting dalam mengurangi korupsi. Begitu pula dengan Najahningrum, 2013 yang menyebutkan bahwa penegakan peraturan berpengaruh negative terhadap kecendrungan kecurangan, hal ini menunjukkan bahwa adanya ketidakpatuhan atas perundang-undangan akan mengakibatkan meningkatnya kecendrungan kecurangan.

Penelitian lainnya terkait temuan audit dan tingkat korupsi dilakukan oleh Masyitoh dkk., 2015 yang menyatakan bahwa temuan audit atas ketidakpatuhan pada perundangundangan berpengaruh positif terhadap persepsi korupsi. Semakin banyak jumlah temuan audit ketidakpatuhan atas perundang-undangan menunjukkan persepsi korupsi yang lebih tingggi.

\section{Temuan Audit Atas Kelemahan Sistem Pengendalian Intern Pada Tahun Lalu Berpengaruh Positif Terhadap Persepsi Korupsi}

Pengungkapan atas ketidakpatuhan terhadap peraturan dan perundang-undangan dalam penyelenggaran pemerintah daerah dibutuhkan untuk memastikan bahwa proses penyelenggaraan pemerintahan daerah telah sesuia dengan undang-undang dan peraturan yang berlaku. Hal serupa dinyatakan oleh Nosworthy (1999) yang berpedapat bahwa salah satu tujuan pemeriksaan adalah untuk meninjau kepatuhan terhadap undang-undang dan peraturan.

Raman dan Wilson (1994) berpendapat bahwa audit dalam instansi pemerintahan memberikan kontribusi untuk memastikan kepatuhan terhadap hukum dan peraturan serta meminimasilisasi tindakan pemborosan, kecurangan dan tindak korupsi. Dwiputrianti (2008) membuat suatu criteria yang menunjukan efektifitas dari laporan hasil pemeriksaan yang menyimpulakan bahwa laporan mengenai kebutuhan terhadap undang-undang dan peraturan yang berlaku (compliance with laws and regulations) merupakan salah satu kriteria yang menunjukan kualitas dari laporan hasil pemeriksaan atas instansi pemerintah.

Mustikarini dan Fitrisari (2012) serta Arifianti et al. (2013) telah membuktikan secara empiris bahwa ketidakpatuhan pemerintah daerah terhadap peraturn dan perundang- 
undangan memiliki dampak yang negatif dan signifikan terhadap penilaian kinerja. Adanya pelanggaran terhadap peraturan yang telah ditetapkan menunjukkan buruknya penyelenggaraan pemerintahan didaerah tersebut. BPK juga menyebutkan bahwa ketidakpatuhan terhadap peraturan dan perundang-undangan dapat menimbulkan adanya kerugian daerah maupun yang berpotensi merugikan daerah, adanya kekurangan penerimaan sehingga memperkecil penerimaan daerah, ketidakhematan, ketidakefesienan, serta ketidakefektifan.

Berdasarkan UU No. 15/2004 dan IHPS BPK, rincian temuan audit terhadap system pengendalian intern adalah sebagai berikut:

1. Kelemahan system pengendalian akuntansi dan pelaporan

a) Pencatatan tidak/belum dilakukan dengan akurat

b) Penyusunan laporan tidak sesuai dengan ketentuan

c) Keterlambatan penyampaian laporan

d) System informasi akuntansi dan pelaporan belum didukung SDM yang memadai

2. Kelemahan system pengendalian pelaksanaan anggaran pendapatan dan belanja

a) Perencanaan kegiatan tidak memadai

b) Kegiatan yang tidak sesuai dengan aturan

c) Penyimpangan terhadap peraturan perundang-undangan

d) Pelaksanaan belanja diluar mekanisme APBD

e) Pelaksanaankebijakan yang tdak tepat

3. Kelemahan struktur pengendalian intern

a) Tidak memiliki SOP yang formal

b) SOP yang ada tidak berjalan secara optimal

c) Tidak adanya satuan pengawasan intern

d) Satuan pengawasan intern yang tidak memadai

e) Tidak ada pemisahan tugas

Temuan Audit Atas Ketidakpatuhan Terhadap Peraturan Dan Perundang-Undangan Pada Tahun Lalu Berpengaruh Positif Terhadap Persepsi Korupsi.

Berdasarkan pasal 20 Undang-Undang Nomor 15 Tahun 2004 tentang Pemeriksaan Pengelolaan dan Tanggung Jawab Keuangan Negara, menyatakan bahwa seluruh pihak yang diperiksa wajib untuk memberikan respon terhadap hasil laporan BPK dan harus diserahkan tidak lebih dari 60 hari setelah laporan diterima. Setelah melakukan proses pemeriksaan atau audit, tahapan berikutnya adalah tahap pemantauan tindak lanjut atas rekomendasi yang diberikan oleh auditor. Tahapan ini penting untuk dilakukan agar rekomendasi yang diusulkan oleh auditor dapat diimplementasikan dengan baik oleh pemerintah daerah.

Dwiputrianti (2008) berpendapat bahwa adanya laporan tindak lanjut hasil temuan dan rekomendasi dalam laporan pemeriksaan menunjukkan kualitas dari suatu laporan hasil pemeriksaan dan laporan ini akan menjadi lebih efektif jika rekomendasi tersebut dilaksanakan oleh organisasi yang telah diperiksa. Selain itu, Umar (2012) berpendapat bahwa dengan adanya masukan dari auditor, pihak pengambil keputusan dapat menghentikan dan mencegah terulangnya kembali kesalahan, penyimpangan, penyelewengan, serta pemborosan. Dengan melaksanakan apa yang telah direkomendasikan oleh auditor, maka pemerintah daerah telah berupaya untuk memberbaiki kesalahan dalam pertanggungjawaban penyelenggaraan Negara. Pembetulan setelah proses audit merupakan suatu bentuk tanggung jawab dari pemerintah daerah atas kesalahan dalam pertanggungjawaban keuangan audit. Tanpa adanya penyelesaian maka temuan audit tidak bermanfaat untuk menciptakan akuntabilitas dalam proses audit pemerintahan demi terciptanya akuntabilitas.

Rincian dari lima klasifikasi temuan audit atas ketidakpatuhan terhadap perundangundangan adalah sebagai berikut;

1. Klasifikasi temuan kerugian Negara/indikasi kerugian Negara

a) Belanja fiktif

b) Tuntutan pembendaharaan 
c) Kemahalan harga, pengadaan barang/jasa oleh entitas yang bernbeda dari penyedia pat yang sama barang dan jasa yang sama pada waktu dan tem

d) Kelebihan pembayaran

e) Kekurangan volume pekerjaan

f) Pembayaran honoranium dan atau biaya perjalanan dinas ganda

g) Indikasi tindak pidana korupsi

h) Pengadaan barang/jasa fiktif

i) Barang/jasa yang diterima tidak sesuai dengan kontrak

j) Rekanan penyedia barang/jasa wanprestasi

k) Asset dikuasai pihak lain

I) Penggunaan uang atau barang untuk kepentingan pribadi

2. Klasifikasi temuan kekurangan penerimaan

a) Pajak/penerimaan Negara bukan pajak/ denda keterlambatan pekerjaan belum atau terlambat dipungut/disetor

b) Penggunaan langsung PNBP/pendapatan (retribusi, kapitasi ASKES,dIl)

c) Sisa uang yang harus dipertanggungjawabkan akhir tahun angggaran tidak disetor/belum ke kas Negara/kas daerah

d) Kelebihan pembayaran subsidi oleh pemerintah

3. Klasifikasi temuan admiinistrasi

a) Pencatatan tidak/belum dilakukan atau tidak akurat

b) Pertanggung jawaban tidak akuntabel (bukti tidak lengkap/tidak sah)

c) Proses pengadaan barang/jasa/lelang profoma

d) Pekerjaan dilaksanakan mendahului kontrak/surat perjanjian kontrak SPK

e) Mekanisme pemungutan dan penyetoran PNBP tidak sesuai dengan ketentuan

f) Pengalihan angggaran antara mata anggaran keluaran / pengeluaran tidak sah

g) Entitas terlambat menyampaikan laporan pertanggungjawaban

h) Salah pembebanan anggaran

i) Kebijakan tidak tepat

j) Penyimpangan terhadap peraturan perundang-undangan bidang teknis tertentu atau ketentuan intern organisasi objek yang diperiksa.

k) Penyimpangan terhadap perautran perundang-undangan bidang pengelolaan perlengkapan atau barang milik Negara/daerah (asset belum didukung oleh bukti kepemilikan yang sah, penghapusan tidak sesuai dengan ketentuan)

I) Penyimpangan dari peraturan tentang pedoman pelaksanaan APBN/APBD

4. Klasifikasi Temuan Kehematan dan Efesiensi

a) Pengadaan barang/jasa melebihi kebutuhan.

b) Penetapan harga standar tidak realistis.

c) Penetapan kualitas dan kuantitas barang/jasa yang digunakan tidak sesuai standar.

d) Ketidakhematan/pemborosan keuangan negara.

5. Klasifikasi Temuan Efektivitas

a) Penggunaan anggaran tidak tepat sasaran/tidak sesuai peruntukkan.

b) Pemanfaatan barang/jasa dilakukan tidak sesuai dengan rencana yang ditetapkan.

c) Barang yang dibeli tidak dimanfaatkan.

d) Pemanfaatan barang/jasa tidak berdampak terhadap pencapaian tujuan organisasi.

e) Pelaksanaan kegiatan terlambat sehingga mempengaruhi pencapaian tujuan organisasi.

\section{Simpulan dan Saran}

Berdasarkan rumusan masalah yang telah kami paparkan adapun hasil dari pemaparan materi tersebut yakni pada rumusan masalah yang pertama yaitu, pengaruh opini audit terhadap tingkat korupsi di Indonesia, sebelum itu kami akan membahas mengenai pengertian dari Opini audit menurut kamus standar akuntansi (Ardiy, 2007) adalah laporan yang diberikan seorang akuntan public terdaftar sebagai hasil penilaiannya atas kewajaran laporan keuangan yang disajikan perusahaan. Opini audit merupakan pernyataan auditor atas kewajaran informasi keuangan yang disajikan dalam laporan keuangan, 
sehingga opini audit dapat digunakan oleh pengguna laporan keuangan dan memberikan keyakinan bahwa informasi audit pada laporan keuangan organisasi lain adalah bahwa opini audit juga menggambarkan kepatuhan atas peraturan perundang-undangan serta efektivitas sistem pengendalian intern. Menurut standar professional akuntan (PSA 29), opini audit terdiri dari 5 jenis yaitu: (1) Opini wajar tanpa pengecualian (Unqualified opinion), (2) Opini Wajar Tanpa Pengecualian dengan Paragraf Penjelasan (Modified Unqualified Opinion), (3) Opini Wajar Dengan Pengecualian (Qualified Opinion), (4) Opini tidak wajar (Adverse Opinion), (5) Opini Tidak Memberikan Pendapat (Disclaimer of opinion). Semakin baik opini audit yang diperoleh menunjukkan semakin rendah potensi korupsi di lingkungan pemerintah daerah sehingga opini audit dihipotesiskan berpengaruh negatif terhadap persepsi korupsi. Berdasarkan penelitian yang dilakukan Huefner (2011), temuan audit atas sistem pengendalian intern dapat digunakan untuk mendeteksi adanya potensi kecurangan dilingkungan pemerintah daerah. Temuan audit adalah himpunan data dan informasi yang dikumpulkan, diolah dan diuji selama melaksanakan tugas audit atas kegiatan instansi tertentu yang disajikan secara analitis menurut unsure-unsurnya yang dianggap bermanfaat bagi pihak-pihak yang berkepentingan. BPK juga menyebutkan bahwa ketidakpatuhan terhadap peraturan dan perundang-undangan dapat menimbulkan adanya kerugian daerah maupun yang berpotensi merugikan daerah, adanya kekurangan penerimaan sehingga memperkecil penerimaan daerah, ketidakhematan, ketidakefesienan, serta ketidakefektifan. Tanpa adanya penyelesaian maka temuan audit tidak bermanfaat untuk menciptakan akuntabilitas dalam proses audit pemerintahan demi terciptanya akuntabilitas.

Berdasarkan pemaparan diatas, saran yang dapat diberikan adalah sebagai berikut.

Dengan adanya penulisan makalah ini, diharapkan penulis dapat memperoleh pengetahuan lebih mengenai Pengaruh Pengawasan Keuangan Pada Daerah-Daerah Di Indonesia Terhadap Tingkat Korupsi Di Indonesia.Dan semoga dengan adanya makalah ini akan dapat memotivasi penulis untuk membuat makalah sejenis dengan informasi yang lebih mendetail lagi. Dengan adanya penulisan makalah ini, diharapkan Pembaca dapat memperoleh pengetahuan lebih mengenai Pengaruh Pengawasan Keuangan Pada Daerah-Daerah Di Indonesia Terhadap Tingkat Korupsi Di Indonesia. Sehingga Pembaca dapat memahami lagi materi yang disampaikan pada makalah sehingga kedepannya tidak ada lagi kesalahpahaman konsep mengenai pengauditan pada organisasi pemerintah dalam konteks Indonesia.

\section{DAFTAR PUSTAKA}

Prayudi, Made Aristia Dan Komang Adi Kurniawan Saputra. 2016. Akuntansi Pemerintahan. Singaraja: Istiqlal Publishing Grup.

www.academia.edu/28468193/MAKALAH INTERNAL AUDIT TEMUAN AUDIT KELOMP OK I Akuntansi F diakses-tanggal 10/12/2016

http://www.reseachgate.net/publication/30446627 Pengaruh Opini Audit Temuan Audit d an Tindak Lanjut Hasil Audit Terhadap Persepsi Korupsi Pada Pemerintah Daera h Tingkat II Tahun 2008-2010 diakses tanggal 11/12/2016

www.kajianpustaka.com/2013/10/pengertian-dan-jenis-jenis-opini-audit.htm/?m=1 diakses tanggal 12/12/2016 